\title{
Cjal's interactions with Sherrington and The Croonian Lecture
}

\author{
Juan A. De Carlos ${ }^{1}$ and Zoltán Molnár ${ }^{2}$
}

${ }^{1}$ Department of Molecular, Cellular and Developmental Neurobiology, Instituto Cajal (C.S.I.C.) Avenida del Doctor Arce, 37, 28002 - Madrid, Spain. e-mail: decarlos@cajal.csic.es

${ }^{2}$ Department of Physiology, Anatomy and Genetics, Sherrington Building, University of Oxford, Parks Road, Oxford, OX1 3PT, UK. e-mail: zoltan.molnar@dpag.ox.ac.uk

\section{Running title:}

Cajal, Sherrington and the Croonian Lecture

\section{Correspondence to:}

Juan A. de Carlos

Avenida del Doctor Arce, 37, 28002 - Madrid, Spain. e-mail: decarlos@cajal.csic.es

Zoltán Molnár

Department of Physiology, Anatomy and Genetics, Sherrington Building, University of Oxford, Oxford, Parks Road, Oxford OX1 3PT, UK. e-mail: zoltan.molnar@dpag.ox.ac.uk

\section{Grant information:}

- Grant sponsor: Spanish Ministry of Economy and Competitiveness; Grant number: BFU 201675299-R 
- Medical Research Council (G00900901); Biotechnology and Biological Sciences Research Council (BB/1021833); The Wellcome Trust (092071/Z/10/Z)

\begin{abstract}
Sherrington was a major proponent of the neuron doctrine and he was inspired by Santiago Ramon y Cajal’s theory of dynamic polarization of nerve cells ('Ley de la polarización dinámica de la célula nerviosa'). Sherrington coined the term "synapse” to name the Cajal description of interneuronal contact and he gave the term, for functional nerve endings, as "Boutons terminaux", still used today. These two giants of neuroscience met only once, but they had a lifelong friendship. It was Sherrington who wrote Cajal's Obituary for the Royal Society. We review here some of the scientific exchanges between Cajal and Sherrington, with particular attention to 1894, when the two neuroscientist met in London during Cajal's visit to deliver the Croonian Lecture to the Royal Society. We shall examine not only the scientific exchanges, but also their friendship, which was immediate and strong.
\end{abstract}

KEY WORDS: Cajal; Sherrington; lectures; epistolary; neuron doctrine. 
Cajal used to say that the year 1888 was his year of fortune, when he made his first and most compelling discoveries about the nervous system. This is the year when Cajal began to study the nervous system, starting with the cerebellum of birds. It was also the year when he described independent cells, free endings (baskets, pericellular nests), dendritic spines on Purkinje cells, the axons of granular cells (parallel fibers), climbing fibers and mossy fibers. He established the "Law of the pericellular contact" and he verified all this in the retina, spinal cord and optic lobe. With all these findings, Cajal convinced Kölliker of the fatuity of the reticular theory in 1889. Another very important year in his life was 1894, when Cajal started to receive honors and nominations from various universities and foreign societies (Figure 1). Michael Foster, then Secretary of the Royal Society of London, invited Cajal to deliver the Croonian Lecture (Figure 2). The Croonian Lectures are prestigious lectureships given at the invitation of the Royal Society and the Royal College of Physicians (https://en.wikipedia.org/wiki/Croonian_Lecture).

Figures 1,2 and 3 
This lecture was a master class that Cajal gave in French with the title "La fine structure des centres nerveux". The lecture was delivered in the headquarters of the Royal Society at “Bourlington House”. To further express the recognition of the Royal Society, Cajal received an honorarium of 50 pounds. Moreover, Cajal was awarded an Honorary degree of Doctor in Science by the University of Cambridge during the same visit. Foster was Sherrington's mentor at Cambridge and it was largely due to Sherrington's influence that the Royal Society invited Cajal to give the 1894 Croonian lecture (Figure 3). On $10^{\text {th }}$ December 1893, Michael Foster, as secretary of the Royal Society, sent to Cajal the following letter (in French):

The Royal Society

Burlington House, London, W.

Dear colleague,

The Royal Society of London used to pronounce each year to its members a speech entitled "The Croonian Lecture" about an issue of biology. For several years, a distinguished foreign scientist has delivered the speech: Helmholtz, Kühne, Kölliker, Roux, Mosso, etc.

On behalf of the Royal Society I have the honor to ask you if you would agree to fulfill that duty in the year 1894. We would like a speech about the results of your work on the nervous system. 
The date that would best suit the Society would be one of the Thursdays of the month of February or March, for example on February 15 or 22.

If the proposal were to your liking, you would receive a fee of $£ 50$.

With the hope of having an affirmative answer, receive, my dear colleague, my most distinguished considerations,

\section{Foster}

Secretary of The R.S.

Cajal regarded the nomination for the Croonian lecture as a great honor. In his autobiography he pointed out that the illustrious Professor Kölliker imparted one of those at the very dates of his own birth, in May 1852, where he explained the nerve endings on the muscles (Ramón y Cajal, 1923). Cajal also wrote that when he received the invitation from the Royal Society he was very impressed, but initially considered that he should not accept it. He thought about the importance of this Society and the prestige of previous nominees and imagined that he would not live up to the very high expectations. It was only after he became aware of the importance of his own work and his seminal discoveries, that he overcame his first reluctance of presenting the lecture. However, before his imminent departure his subconscious struck again; one of his daughters fell ill and Cajal again contemplated declining the invitation. However, his close friend and family doctor, Dr. Hernando, reassured him that he would take care of Cajal's daughter himself. 
Silveria, his wife, was also reassured by the words of Dr. Hernando and she personally insisted that Cajal travel to England. The kind letters of Professors Foster convinced Cajal to accept the invitation to deliver the Croonian Lecture. In addition, Sherrington (Figure 3), the brilliant young physiologist, invited Cajal to stay with his family at his house in London.

On December 16, 1893, Cajal answered Foster with the following letter, in French, which is preserved in the archives of the Royal Society:

Very honorable colleague,

I accept with great pleasure the honor that your wise Royal Society confers me to impart the "Croonian Lecture" of 1894. I thank you because it is a very high honor for my modest merits.

Before writing the speech, I beg you if you can give me information on the following points:

1. The approximate duration of the speech.

2. If I can use figures and annexes schemes.

3. If I am allowed to use the French language because, unfortunately, although I am able to translate English, I do not speak it.

4. Let me know if a simple talk will be enough or if you prefer that I give an elaborate speech in French. In this last case I would be very uncomfortable because I am still far from mastering the French language. 
As for the date of the conference, it could be set, if there is no problem, for the first or second Thursday of March.

Waiting for your reply I have the honor to send you my most sincere friendship.

S. Ramón y Cajal

Four days later, on December 20, Foster reply to Cajal with the following letter written in English:

The Royal Society

Burlington House, London, W.

Dear colleague,

The fact that in your letter you say that can read in English encourages me to write you in my own language, but if it causes you the slightest problem, I beg you to tell me, and I will return to French.

It is unnecessary to tell you the pleasure that causes me, as well as all English physiologists, the fact that you can come to give the lecture. 
The conference should last about an hour, and I suggest that you show us the current situation and the most important results of your histological research on the nervous system, adding all the physiological considerations that you consider appropriate.

I believe that French will be the best option. We cannot hope you speak to us in English, and relatively few of us understand Spanish. The conference should be a simple conference, not a speech and, the simpler, the better!

We have large rooms in which to place figures, but I would suggest that you make use of our Electric Lantern. We have a projection microscope for conventional microscopic preparations and we can also show the photographs in the form of transparencies. If you send us your drawings or photographs we can turn them into slides, ready for you to use.

Several friends of London will have the honor of entertain you during your stay in that city. And I hope you have enough time to visit Cambridge, where I have my residence.

If you are married, I hope you will be able to persuade your wife to accompany you, unless you are afraid of our horrible English climate.

With my best wishes,

Yours sincerely.

M. Foster

Professor Foster would send several more letters before Cajal departed for London. 
It was customary that when a foreign professor was invited to give the Croonian Lecture, according to the studies of the candidate, he was awarded an Honorary degree of Doctor Scientiae (D. Sc.) either at Oxford or Cambridge, in a solemn ceremony.

Based on this, Foster wrote to Cajal on 13 February 1894 to ask if he would accept the Honorary degree of Doctor of Science from Cambridge, and so be able to prepare the ceremony (Figure 4):

\section{Shelford}

Cambridge

Feb 13

My dear colleague,

I am instructed by the Vice Chancellor to ask you to accept from the University of Cambridge the Honorary degree of D. Sc (Doctor Scientiae). It is necessary that you should be present at Cambridge to receive it.

Can you come over to England in time to be at Cambridge on March $1^{\text {st }}$ ? This would be by far the most convenient day for the University. If you cannot come on March $1^{\text {st }}$, it must be some day between March 1 and March 8. It cannot be given after March 8.

Would you kindly telegraph thus to the Vice-Chancellor?

Cajal, can come March $1^{\text {st }}$ or come after March $1^{\text {st }}$ ? The latter will mean that the degree will be given to you between March 1 and March 8, probably March 6.

What is your name in full? 
(?D.) Santiago Ramón -y-Cajal?

Ever yours truly

M. Foster

Figure 4

As expected, Cajal accepted the Honorary Doctor of Science Degree from Cambridge University and he began to prepare his lecture in French, considering that his English was too bad for a decent talk. He also prepared a selection of his best histological preparations on the cerebellum, retina, medulla, and olfactory bulb and, at the time of the trip, he also took his Zeiss microscope. Before that, he received another letter from Foster asking for a summary of his presentation to facilitate its follow-up by attendees.

During his trip to London he passed through Paris and greeted his friend Matias Duval and had the opportunity to meet Dr. Leon Azoulay who was kind enough to review and correct the French of his presentation. It was Azoulay who translated many of Cajal's publications to French, including Histologie du Système Nerveux de l'Homme et des Vertébrés (Ramón y Cajal, 1909). In London he was welcomed with tremendous hospitality by Professor Foster and a number of distinguished members of the Royal Society, including Professors Schäfer, Klein, Bourdon-Sanderson, Horsley, Mott and their President, Sir W. Thomson (Lord Kelvin). Cajal 
was highly impressed by all of them, because, even though they belonged to a group of the most illustrious scientists in England, they were enormously simple and modest, lacking their deserved professional pride.

Eccles and Gibson (1979) wrote: "Sherrington had taken on more than he had bargained for in inviting Cajal to be his guest in London. Mrs. Sherrington was to discover that Spaniards stripped their beds each day and hung the bedding out of the window, to the consternation of the neighbors and of the weather prophets in the uncertain climate of London. She also found that Cajal kept his bedroom door locked all day, to protect the little laboratory which he had set up in order to give the final touches to his silver staining of the nervous tissue.”

Putting the bedding out of the window, which is customary in most Mediterranean and Central European countries, must have made a great impression in London, because it appears in the memories of C.E.R. Sherrington, Sir Charles Sherrington's son. He wrote about Cajal's visit to London (Appendix 17 in Eccles and Gibson, 1979): “Ramón y Cajal was a guest at St George’s Square and caused some embarrassment since, before leaving the house after breakfast he had locked his room, his lantern slides being arranged all over the floor for a lecture that evening. My mother wondered why all the neighbors were gesticulating and pointing to the house. She went to find out - in true Spanish style all the bedclothes of her guest were draped from the balcony. Nothing could be done until Ramón y Cajal returned, key in pocket.”

The first event that Cajal attended in England was to receive his Honorary Doctorate of Science at Cambridge on $6^{\text {th }}$ of March. Therefore, Cajal had to travel from London to Cambridge. 
The very entertaining story of Cajal's arrival in Cambridge for his honorary doctorate is told by Eccles and Gibson (1979): "Sherrington has to go up the day before for some business and his wife had to put Cajal on the Cambridge train from Liverpool Street. On the appointed day, she was anxious to get Cajal ready ahead of time. The cab driver was summoned and given an especially large payment with instructions to put Cajal on the Cambridge train. This he did with enthusiasm because of the large "bribe”, whipping up his horse and arriving in record time. The result was that Cajal was rushed by the cabbie to an earlier train to Cambridge than the agreed one. He arrived in Cambridge forgetful of why he was there with no one on the platform to meet him when he was delivered from the then empty train at Cambridge. He wandered down the street, and passing Emmanuel College, he proceeded to sketch its attractive façade, standing in the middle of the street and blocking traffic. When requested to move he could not understand and seemed so lost that the police took charge of him.”

"Meanwhile, the correct train had arrived without Cajal, to consternation of the waiting Sherrington. So, he telegraphed his wife asking "Why no Cajal?” She laconically replied by return telegraph - there were no telephones in those days - "Cajal consigned by the 11.10 train". But of course, this telegraphic exchange took an hour or so and meanwhile the Vice Chancellor's lunch in honor of Cajal, the graduand, had to be held without him. Eventually an enquiry to the police elicited the reply, "we have a fellow along at the station who may be your man. So Cajal was rescued in time for the graduation ceremony but without his lunch!”. 
The ceremony was held in the Senate House and Cajal stayed in a guesthouse of King's College. Later, Cajal said that the ceremony was held according to the most ancient canons, where teachers and students were dressed in the traditional academic costumes of a doctor consisting of a red robe and a graduation cap.

Back in London he stayed at the house of Charles Sherrington. In his Recuerdos de mi vida, Cajal wrote that Sherrington gave up everything in his daily routine to take him to the British Museum, the Royal College of Surgeons, three medical schools, the laboratories of Ferrier, Schäfer and Mott, and some touristic sites and memorials, such as the Westminster Abby to see the memorials to Newton and Darwin.

Sherrington also assisted Cajal in the preparation of his presentation for the Croonian Lecture. Cajal brought his collection of microscope slides with him to London for his presentation and Sherrington made lantern slides of some of these microscope slides. In fact, he made a series of microphotographs from Cajal's best histological preparations in order to be projected using the Magic Lantern. In addition, Sherrington provided all the material to draw large illustrations in various colors.

Eccles and Gibson (1979) wrote: "It was difficult to convince Cajal that not all those attending his lecture at the Royal Society's rooms in Burlington House would line up for even a rapid look at his preparations under the microscope. Sherrington quietly prepared lantern slides of many of the specimens, but Cajal was at first unwilling to use them. He was, however, so impressed by what he later described as “... the hospitality of Ch. Sherrington and his admirable wife, 
provided with such attention and finesse..." that he relented and permitted a few slides to be projected. The fact that Sherrington had provided large flags of Britain and Spain intertwined and a good supply of champagne, impressed his visitor mightily. Michael Foster at the Royal Society dinner remarked that Cajal had transformed the impenetrable forest of the nervous system into a well-kept park! The Spanish Ambassador told his audience that the three most memorable occasions in his life were his first sight of Niagara Falls, his first view of the Coliseum in Rome, and listening to Cajal's lecture to the Royal Society.”

Some of Cajal's slides remained at Oxford. In 1985 William C. Gibson donated two photomicrographs to the Oxford University Laboratory of Physiology that Sir Charles Sherrington prepared (see Figure 5, part B).

Using the lantern slides, one of us (JADC) identified the original Cajal slide at the Cajal Institute in Madrid from which Sherrington took the prints (compare panels B and C of Figure 5). Cajal's drawings of a very similar slide were published in Histologie du Système Nerveux de l'Homme et des Vertébrés, Fig. 6 on page 6 (Ramón y Cajal, 1909). Therefore, Cajal probably took most of his slides back with him to Madrid.

\section{Figure 5}

Collections of Sherrington's histological preparations are preserved at Department of Physiology, Anatomy and Genetics at University of Oxford (Molnár and Brown, 2010; https:/history.medsci.ox.ac.uk/slides/). We searched for slides originating from Cajal in 
Sherrington's box, and found some with his signature Ramón y Cajal (https://cslide.medsci.ox.ac.uk/items/view/458 and https://cslide.medsci.ox.ac.uk/items/view/86. These are cat spinal cord preparations (Figure 5 panel A). We also found some slides labelled with the inscription Cajal, with different handwriting, but these are most probably referring to the method used for silver impregnation (see: https://cslide.medsci.ox.ac.uk/items/view/478). These might have been produced in Sherrington's laboratory based on the methods used by Cajal.

The Croonian Lecture was scheduled for 8 March 1894 at Burlington House (near Piccadilly) where the Society had its headquarters in those years. Lord Kelvin presided at the meeting and the English and Spanish flags were both displayed on the podium. In his lecture Cajal talked about the latest advances in the morphology and connections of nerve cells. His lecture was entitled "La Fine Structure des Centres Nerveux" and was published in the Proc. Royal Society (Ramón y Cajal, 1894). In his lecture he covered a huge area of research. He talked about the sensory and motor circuits of the spinal cord, the sensory and the sympathetic ganglia of the spinal cord, olfactory system, retina and visual system, cerebellum and cerebral cortex. He concluded that it would be a great challenge to compare the neuronal circuits of various animals with human. It goes without saying that the conference was a resounding success. After the academic presentation, the Royal Society invited the participants to a banquet where numerous personalities toasted warmly in honor of the English and Spanish sciences. 
In the subsequent days, Cajal took advantage of visiting and discovering London, Oxford and Cambridge. He reported about these travels in a letter to Julian Calleja on March 11, where also reflected the impressions about his conference.

\section{Figure 6}

Julián Calleja (Figure 6) was the dean of the Medical School in Madrid and a very influential person at that time. The transcription of the letter is as follows (Figure 7):

London, March 11, 1894

My dear don Julian,

Thank you very much for the telegram that you have sent to me on behalf of the school of medicine, congratulating me for my conference.

This turned out very nice, if I believe the opinion of my friend here. This was due, no doubt, to the large number of drawings of great size that I presented. And also, to the projection, with the Magic Lantern, of 10 or 12 microphotographs taken of my preparations.

I was very well-received and several members of the Royal Society took the floor to thank me and to praise my work. Then we went to a restaurant where the neurological and physiological London societies gave a banquet of more than 70 diners. 
Professor Foster made a toast to the Spanish nation, commend my work again and he ended up drinking to the health of the Queens of Spain and England. After several speeches and my own saying thanks, ended the ceremony plying the piano and singing the Spanish and English national anthems. The ceremony, as you can see, was very friendly to our country.

Today, I have to go again to Cambridge, invited by Professor Foster to attend a meeting, held once a year, with professors from other universities. Tomorrow I will go to Oxford, invited by Professor Sanderson.

Here, there are a lot to admire and learn, concerning laboratories, libraries, and practical teaching. However, the teaching of the histology, only theoretical, leaves something to desire due to the very special regime of the English colleges paid and sustained by private companies. But of this we will talk more on my return.

Appreciating the memory of my faculty colleagues is pleased to put at your service your friend and colleague,

S. Ramón y Cajal

Cajal returned to Spain passing through Paris again, where he made a stopover of several days to see some colleagues (Duval, Dejerine, Marie, etc.) and to give a talk. 
One of the most interesting things for Cajal on his trip to England was meeting Professor Charles Scott Sherrington (1857-1952). Sherrington was an excellent physiologist who established the concept of the integrative action of the nervous system, linking together various reflexes, tone and posture. He was also the main proponent of the concept of inhibition. He would be awarded the Nobel Prize in Medicine or Physiology of the year 1932. In the Madrid Cajal Institute, there is a letter from Sherrington to Cajal, responding to Cajal's congratulations he received shortly after his Nobel Prize, in $9^{\text {th }}$ August 1933, and mentioned the visit of Cajal to London in his letter (Figure 7).

\section{Figure 7}

Sherrington made important contributions to the field of neurophysiology and neurology. One of the lasting legacies of his work was to introduce the term "synapse" to name the relation by contiguity among neurons, described by Cajal (Sherrington in Foster’s Textbook of Physiology, 1897).

Sherrington and Cajal met only once, but they had a life-long friendship. Cajal and Sherrington shared several views on the organization of the nervous system, contiguity, importance of the synapse, convergence and divergence of neural connections, although they devoted different importance to inhibition. The close friendship between Sherrington and Cajal lasted throughout their lives. It was Sherrington who wrote Cajal's Obituary for the Royal Society (Sherrington, 1935). 


\section{ACKNOWLEDGEMENTS}

The authors are grateful to Instituto Cajal (CSIC) for share two original letters for reproduction and to Professor Richard Brown for his helpful comments on the manuscript.

\section{LITERATURE CITED}

Eccles JC, Gibson WC. 1979. Sherrington His Life and Thought (Springer-Verlag Berlin, Heidelberg).

History of Medical Sciences Project, University of Oxford: The histological slides can be viewed: https://cslide.medsci.ox.ac.uk/items/view/806

Molnár Z, Brown RE. 2010. Insights into the life and work of Sir Charles Sherrington. Nat Rev Neurosci 11(6):429-36.

Ramón y Cajal S. 1923. Recuerdos de mi vida. Primera parte: Mi infancia y juventud. Segunda parte: Historia de mi labor científica. Madrid. Imprenta de Juan Pueyo. $3^{a}$ edición, 444 páginas.

Ramón y Cajal S. 1909, 1911. Histologie du Système Nerveux de l'Homme et des Vertébrés. Translated by Léon Azoulay. A. Maloine, ed. (Paris).

Ramón y Cajal S. 1889. Sur la morphologie et les connexions des éléments de la rétine des oiseaux. Anatomischer Anzeiger 4:111-121.

Ramón y Cajal S. 1894. The Croonian Lecture: La Fine Structure des Centres Nerveux. Proc. Royal Society, 55:444-468.

Sherrington CS. 1935. Santiago Ramón y Cajal, 1852-1934. Obituary Notices of Fellows of the Royal Society, 1:425-441.

Sherrington CS. 1897. in Foster M; Textbook of Physiology, volume 3 (7th ed.). London: Macmillan. p. 929. 


\section{FIGURE LEGEND}

\section{Figure 1.}

Santiago Ramón y Cajal (1852-1934)

Figure 2.

Michael Foster (1836-1907)

\section{Figure 3.}

Charles Scott Sherrington (1857-1952)

\section{Figure 4.}

The original letter of Foster dated February 13, 1894. In this letter Foster asked if Cajal would accept the Honorary degree of Doctor of Science at Cambridge, and so be able to prepare the ceremony. Original letter is conserved at the Instituto Cajal, Madrid. 


\section{Figure 5.}

Some histological sections in Sherrington's Histological Slide collections with the signature of Cajal (A), and an example of the lantern slides prepared from Cajal's histological preparations (found at Oxford, B) and the originals (at the Instituto Cajal, Madrid C, D) and corresponding image from Cajal's publication (E).

A: A slide from the third row of Tray 1 in the Sherrington histological box, University of Oxford with the signature of R. y Cajal. More slides with similar staining were found in the same tray with the inscription of Cajal; these are likely to refer to the method used for the staining rather than the origin of the slide.

B: Photomicrograph taken from the lantern slides that Sherrington printed from microscope slides that Ramón y Cajal brought from Madrid for his Croonian Lecture in 1894. The photographs were donated to the University Laboratory of Physiology in 1985 by William C. Gibson. We searched for slides [that could have originated] from Cajal in Sherrington's box, but did not find any.

C: Photomicrograph taken from the original Cajal slide by one of us (JADC) at the Instituto Cajal, Madrid, from which Sherrington took the prints (compare the encircled region at C with B). 
D: High power image from a Golgi impregnated Purkinje neuron from Cajal's original section kept in Instituto Cajal, Madrid.

E: Cajal's illustration taken from a very similar (but not identical) Purkinje cell, which can be seen on Sherrington's lantern slide in B. From Fig. 6 (page 6) of REF 4; a: axon; b: recurrent collateral; c: holes occupied by capillaries; d: holes occupied by basket cells. Image from Instituto Cajal, Madrid, Spain.

The figure is reproduced from Molnár and Brown, 2010 where it appeared as supplementary Figure 6.

\section{Figure 6.}

Julián Calleja y Sánchez (1836-1913)

\section{Figure 7.}

Sherrington's response to Cajal who congratulated him shortly after his Nobel Prize. Sherrington mentioned the 'old' visit of Cajal to London in his letter. The letter is archived at the History of Medical Sciences Project, University of Oxford website: https://cslide.medsci.ox.ac.uk/items/view/2573; original is at Instituto Cajal, Madrid. 

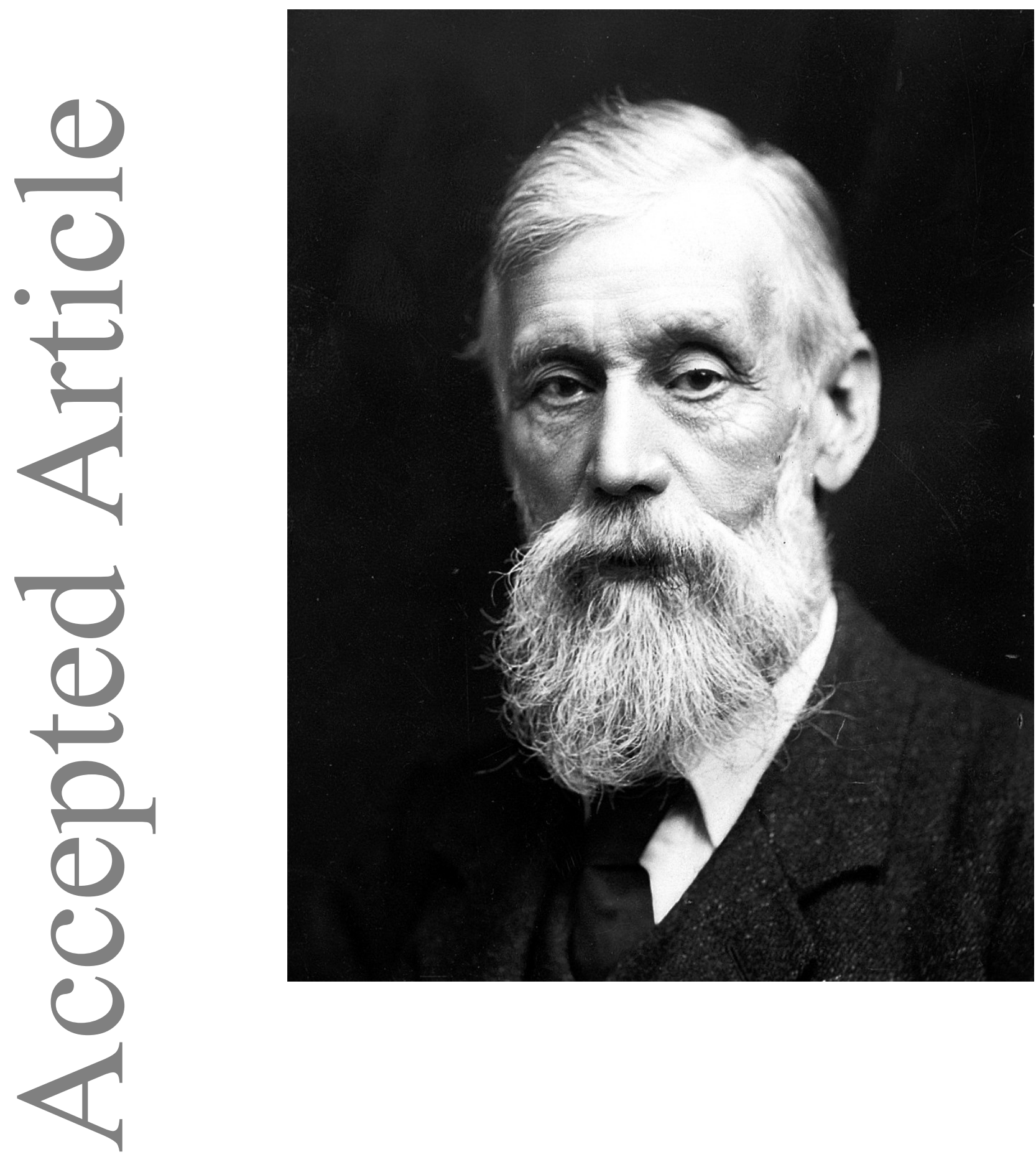

This article is protected by copyright. All rights reserved. 

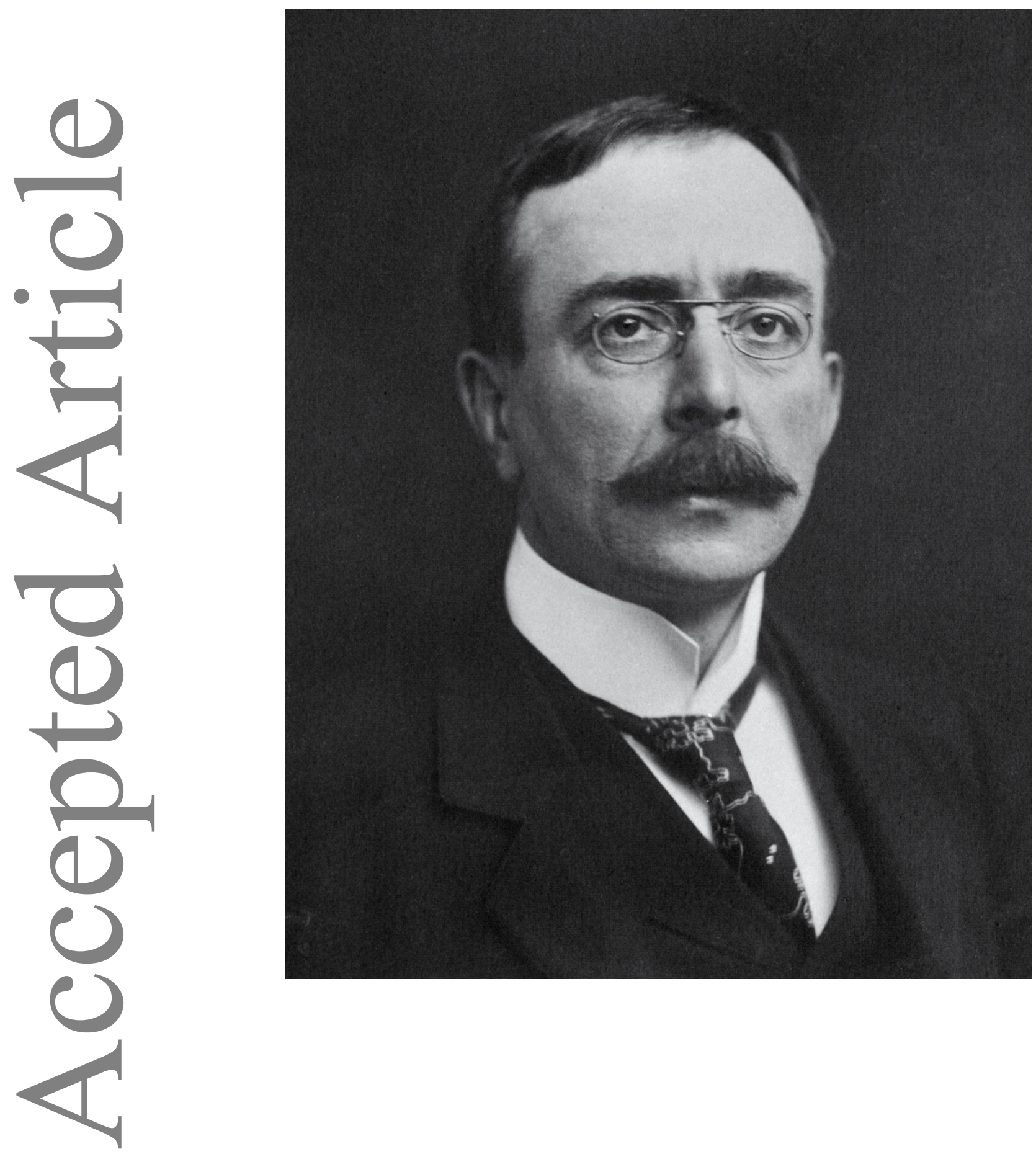


\section{5}

to recects iL.

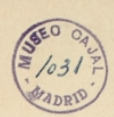

Shreford caculinage

Can you cone ouer to My dear Polleapue. Zel $3^{1 / 4}$ sugland ui time to be at caulinge on Thusday llearchl. sl Ther will be fy tar the mot converient day for the univenty. If you caun ot cone. on marteyst thert a sone doy betrocen

I aus isistmeted iy the Vice cliancellor is ask you to a ccefur from the Revivensity of Cakulure the Honowy depree of D. Sc (Doelor scinitial. It is hecessan that yor should be 
March I. acad Mards 8": If caubill be gurea afles tranch 8 .

would you keindly telegraptr thas

To. Vice. Charecellon Cambinge

Carr come hants! carcl.

of come after llániti!

The latler will mean chat che depiee conle be juien to yos belwees thande

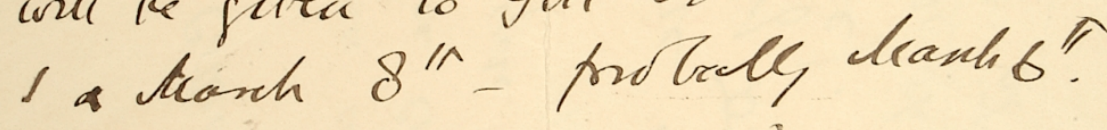
What is your name ca full.'

(?D.) Santiago Ramon-y. Cajal

sogow incy

(e13435

h. Foler

This article is protected by copyright. All rights reserved. 

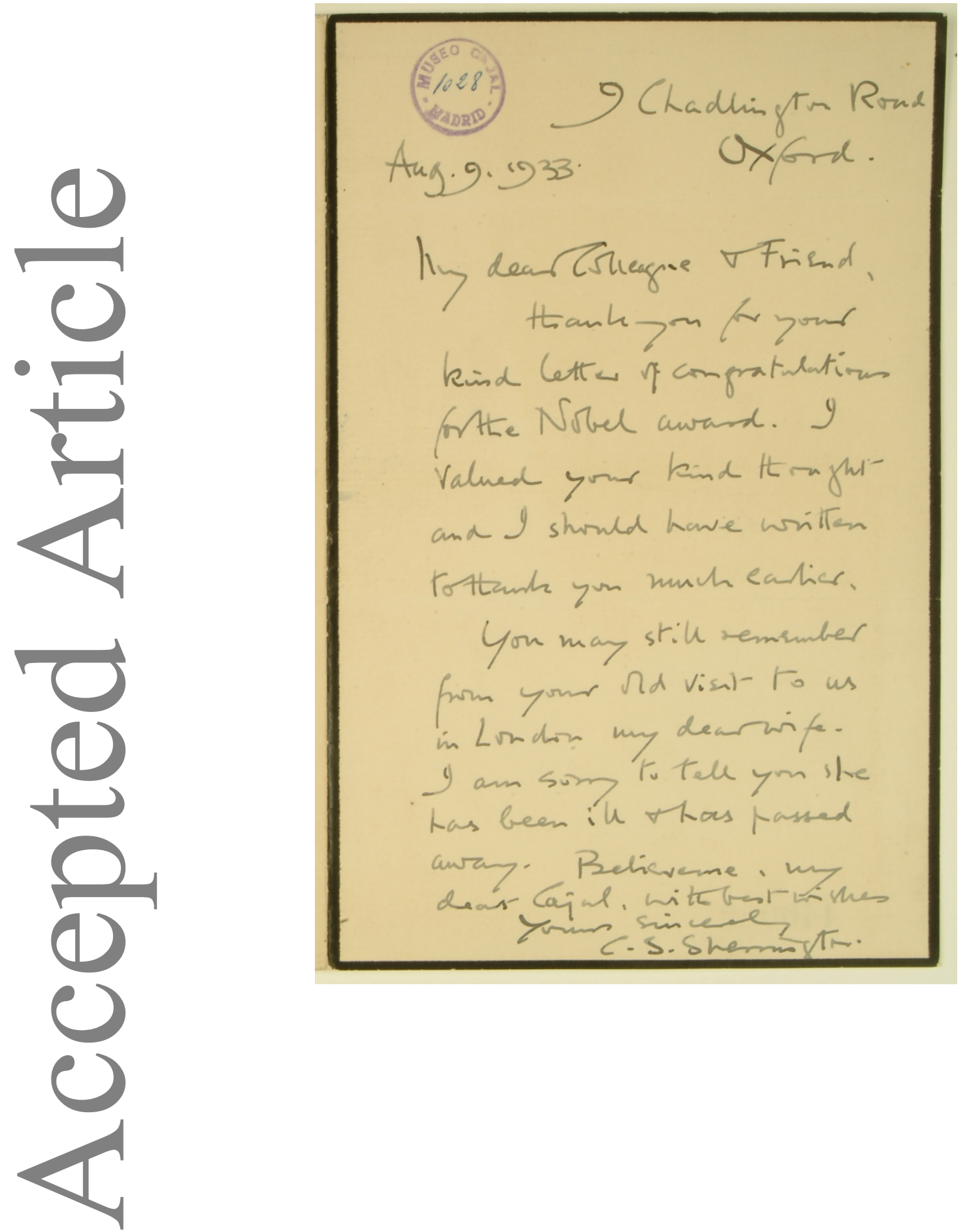